https://doi.org/10.48009/2_iis_2009_430-438

\title{
AN EMPIRICAL STUDY OF THE RELATIVE IMPORTANCE OF SPECIFIC TECHNOLOGY SKILLS, GENERAL BUSINESS SKILLS, AND GENERAL TECHNOLOGY SKILLS
}

\author{
Alan R. Peslak, Penn State University, arp14@psu.edu \\ Gary A. Davis, Robert Morris University, davis@ rmu.edu
}

\begin{abstract}
A large volume of anecdotal research suggests that for today's information technology (IT) and information systems (IS) professional, the importance of technology skills has been superseded by the importance of business, teamwork, and general application skills. This manuscript studies the importance of a variety of specific technology skills, as well as, general technology skills, and general business skills. The study is the start of a concerted attempt to empirically determine whether general technology skills are deemed more important than specific technology skills and also how general technology skills compare to general business skills.
\end{abstract}

A detailed survey of professionals in the Pittsburgh metropolitan area was performed and specific hypotheses related to these skills were tested. Generally, it was found that for information technology professionals; general technology skills were found to be the most significant expertise desired by today's information technology professional community. General technology skills were found to be significantly more important than specific technology skills. Further, general business skills were found not to be significantly more important than general technology skills. General technology skills were found to be more important than general business skills, but this difference was not statistically significant.

The overall findings suggest that general skills, both in technology and business, are most important for entry-level IT/IS professionals. This study, though nascent, provides an interesting start in determining the key topics that should be included in today's information technology curricula.

Keywords: Information Technology Skills, Information System Skills, General Business Skills, IT Skills Gap, IT Curriculum Development

\section{INTRODUCTION}

One of the most important issues for Information Technology (IT) and Information Systems (IS) curricula in higher education is what skills are most important and useful for today's graduates. There is a significant amount of anecdotal evidence that suggests that soft skills have become increasingly important in the IT/IS workforce with the rising advent of outsourcing. Infoworld suggests:

The temptation is to scoff at so-called experts who tell you how to get ahead. But if you're looking for career advancement and the higher pay that goes with it, there may be something to the advice by Bennett Ockrim, vice president of Professional Services at Spherion. ... At the core, outsourcing may be the reason why if you're a tech person you may need to brush up on what Ockrim calls your soft skills. Tech people are becoming a dime a dozen, literally, so you need something more. You need to prove to a potential employer that you can add value to the company beyond your technical qualifications. Companies are no longer willing to just spend money on a lot of pricey software engineers. As I said they are easy to come by now. Instead, they look at an individual applying for a job and think of him or her as a long-term investment. They want a return on that investment and that goes beyond your technical expertise." The enterprise is looking for people who can ascend beyond the technical realm and have an appreciation for the critical business issues of the day," Ockrim advices. So what are some of the attributes needed by a person who has spent most of his career in IT in order to move farther up the corporate ladder? Be a good listener and have an appreciation for business in general. You need to understand the top line and bottom line dynamics of the company and also understand the issues around market demand and what satisfies that demand. [15]

There are many other popular press articles and blogs 
that suggest that specific technical skills are not as important as they once were. This manuscript is a quantitative, statistical study in determining the relative truth of this anecdotal reporting.

\section{RELATED RESEARCH}

There have been numerous and extensive studies relating to IT/IS skills needed by industry. Previous authors have employed various methods to conduct their research and analyze findings. These methods to gather IT/IS skills data include, but are not limited to, surveying employers, surveying recent graduates, surveying recruiters, analyzing employment postings, and reviewing model curricula.

A common research approach is to solicit input concerning IT/IS skills directly from employers. Dillon and Kruck [6], for example, surveyed 128 employers who hired students from an undergraduate Accounting Information Systems Program in their 2008 study. Using a similar approach in their research, Cappel [3] solicited employers' perceptions of technical and non-technical skills in 75 organizations that employed IT/IS graduates from a large public university in the Midwest. Cappel found that the demand for web-based programming skills was increasing, as well as, the demand for communication and problem-solving skills.

Another approach that is often used to gather input on IT/IS skills is to seek input from recent graduates. In order to develop a list of key skills that business and information system's curricula should contain, Boyle and Strong [2] surveyed 105 recent graduates concerning ERP (Enterprise Resource Planning) and other IT/IS job-related skills. In their 2006 study, Davis and Woodward [5] surveyed 222 graduates from a Midwestern University's Information Systems program. Davis and Woodward found that the graduates in their study reported the need for strong "soft-skills" in order to be successful in IT/IS.

Some researchers have used less direct channels for obtaining data on IT/IS skills. For example, many studies have analyzed IT/IS job postings and descriptions. Koong, Liu, and Liu [9] analyzed job posting data from two popular Internet job portals: Monster.com and Hotjobs.com. Koong, et al., discovered that communication skills and managerial expertise topped the list of skills solicited in ITrelated job descriptions. Rather than examine jobsearch portals, Lee and Han [11] collected and analyzed 837 IT/IS positions posted on various Fortune 500 websites. Finally, Kovacs, Davis, and

Volume X, No. 2, 2009
Caputo [10] determined the demand and relative change in demand for IT/IS skills by analyzing keywords over a three-year period from a regional trade association's job portal. Kovacs, et al., found that employers were seeking web development skills, but also communication skills to fill their IT/ISrelated positions.

In addition to gathering IT/IS skill data from employers and Internet job portals, many researchers have surveyed IT/IS recruiters. Martz and Landof [13] surveyed 75 graduates and 18 IT/IS recruiters to develop a list of the top five business and information technology skills needed most by employers. In their more recent, 2008 study, Lee and Fang [12] also surveyed students and recruiters to determine what IT/IS skills are needed by industry and what perception gaps exist between industry and graduating seniors in IT/IS degree programs. Lee and Fang found, as in many other studies, that employers are seeking team skills, communication skills, and critical thinking skills in candidates for IT/IS positions.

Although most prior studies have made recommendations for improving IT/IS curricula, many studies have directly compared employer needs to model curricula. In addition to analyzing job postings of Fortune 500 companies, Lee and Han [11] also compared survey results directly to the content of the IS2002. More specifically, Kim, Hsu, and Stern [8] compared survey results obtained from employers to the content of the Information Systems 2002 (IS2002) model curriculum. Kim, et al., found that project management, e-business, systems analysis and design, and fundamentals of information systems to be the most sought-after skills in IT/IS.

The above-mentioned researchers all reviewed specific aspects of skills deemed necessary by industry. However, none of the authors cited above compared general business skills to general technology skills and general technology skills to specific technology skills. Further, none of the aforementioned studies used the classifications of general business skills, general technology skills, and specific technology skills.

\section{METHODOLOGY}

The specific questions proposed in the current study explore both specific and general skills in business and technology. A brainstorming session was initially held between business professionals and the authors. The approach of the sessions was to develop a list of 
significant technologies and skills to be used as the basis for an industry survey. Each category of general business skills, general technology skills, and specific technology skills was explored. The final survey that was prepared included both broad and detailed questions in each area.

The web-based survey was sent to 44 supervisors employed in Pittsburgh metropolitan-area industries. The list of supervisors was obtained from a database of employers who hired student interns from a medium-sized university in the Pittsburgh area. The response rate was $41 \%$, which is a very high response rate for an online survey. The high rate of participation was most likely due to the positive relationships that exist between the university's internship program and the local employers.

\section{HYPOTHESES}

As a result of reviewing the popular press, the literature, as well as the brainstorm results, hypotheses were proposed to determine the relative importance of general business skills versus general technology skills versus specific technology skills.

Since business and soft skills have been recognized as increasingly important, the following hypothesis was proposed:

H1: General business skills will be ranked as more important than general technology skills for today's information technology professional.

Table 1a Respondents' Rankings of Specific Technology Skills
With the globalization of IT skills the importance of specific skills seems to be deemphasized. Therefore, the following hypothesis was proposed:

H2: General technology skills will be ranked as more important than specific technology skills for today's information technology professional.

Finally, the relationship between general business skills and specific technology skills is explored in the final hypothesis:

H3: General business skills will be ranked as more important than specific technology skills for today's information technology professional.

\section{ANALYSIS OF FINDINGS}

The detailed results of the survey are first presented in Tables 1a, 1b, and 1c. Table 1a lists the survey results related to specific technology skills. Table $1 \mathrm{~b}$ lists the results related to general business skills. Finally, Table 1c lists the results regarding general technology skills.

The scale used for the survey was from 1 to 10 ; thus a neutral importance rating would be 5.5. In the survey, all skill topics were rated above 5.5, except Linux, which was below at 5.22. However, some skills were viewed as more important than others. First, the hypotheses are tested and then a detailed discussion of each topic is presented.

\begin{tabular}{|l|c|}
\hline Skill Topic & Mean Scores \\
\hline MS Office & 7.60 \\
\hline Specific technology skills overall & 7.06 \\
\hline Routers & 6.33 \\
\hline Cisco router technology & 6.22 \\
\hline Oracle database technology & 6.17 \\
\hline MS Visual Studio & 6.11 \\
\hline Visual Basic & 5.76 \\
\hline Linux & 5.22 \\
\hline SQL & Added via comments \\
\hline Spreadsheets & Added via comments \\
\hline MySQL & Added via comments \\
\hline Microsoft technology & Added via comments \\
\hline
\end{tabular}

\footnotetext{
${ }^{1}$ These skill topics were added by the survey respondents via the "Additional Comments" fields of the survey
} 
Table $1 \mathrm{~b}$

Respondents' Rankings of General Business Skills

\begin{tabular}{|l|c|}
\hline Skill Topic & Mean Scores \\
\hline Ethics and professionalism & 9.50 \\
\hline Teamwork & 9.11 \\
\hline Communications & 8.78 \\
\hline Interpersonal skills & 8.76 \\
\hline Organizational problem solving & 8.56 \\
\hline Creativity & 8.11 \\
\hline General business skills overall & 7.83 \\
\hline Leadership & 7.78 \\
\hline Functional business areas & 7.11 \\
\hline Evaluation of business performance & 6.50 \\
\hline Business models & 5.94 \\
\hline Knowledge of Business & Added via comments \\
\hline Customer orientation & Added via comments \\
\hline
\end{tabular}

Table 1c

Respondents' Rankings of General Technology Skills

\begin{tabular}{|l|c|}
\hline Skill Topic & Mean Scores \\
\hline General technology skills overall & 8.33 \\
\hline IT project management & 8.00 \\
\hline Testing & 7.61 \\
\hline Security & 7.56 \\
\hline Systems analysis and design & 7.28 \\
\hline Application development & 7.17 \\
\hline Systems integration & 7.06 \\
\hline Systems networking and infrastructure & 7.00 \\
\hline Maintenance & 6.94 \\
\hline Business process design & 6.72 \\
\hline Programming & 6.72 \\
\hline Operating systems management & 6.67 \\
\hline Internet systems architecture and development & 6.61 \\
\hline Strategic utilization of IT and planning & 6.56 \\
\hline Database design and administration & 6.33 \\
\hline Web page development & 5.61 \\
\hline Human-computer interaction & 5.56 \\
\hline
\end{tabular}

These tables, though informative, do not provide answers to the questions posed in the hypotheses. In order to address the questions proposed in the hypotheses, a series of paired-sample T-Tests was conducted. A key purpose of the study was specifically to determine differences in need for general versus specific skills as well as business versus technology. The basic statistics for each pairing are shown in Table 2 and the significance test results are shown in Table 3.

\section{Hypotheses Testing Results}

Issues in Information Systems 
As cited in the review of past studies, many organizations are seeking general business skills in new hires. This demand for a broad set of business acumen is also seen in job postings for IT/IS positions. To test these anecdotal reports, this study tested the following hypothesis:

H1: General business skills will be ranked as more important than general technology skills for today's information technology professional.

Overall, general business skills scored a 7.83 ranking in importance versus an 8.33 score for general technology skills. However, this difference was not significantly different at the $95 \%$ confidence level $(p$ $=.319)$. Since the difference was not statistically significant, Hypothesis 1 was rejected (i.e., General business skills were not ranked as more important than general technology skills).

The relationship between general business skills and specific technology skills was explored in the second hypothesis:

H2: General technology skills will be ranked as more important than specific technology skills for today's information technology professional.

General knowledge of technology scored an 8.33, which was statistically significantly above the specific technology skills score of 7.06 (at the 95\% confidence level). Due to the statistical significance ( $p=.044)$, Hypothesis 2 was accepted (i.e., general technology skills were ranked as more important than specific technology skills).

Finally, the relationship between general business skills and specific technology skills was explored in the third hypothesis:

H3: General business skills will be ranked as more important than specific technology skills for today's information technology professional.

Overall, general business skills were ranked as more important than specific technology skills (i.e., 7.83 versus 7.06). However, this difference was not statistically significant at the $95 \%$ confidence level ( $p$ $=.202)$. Since the difference was not statistically significant, Hypothesis 3 was rejected.

The results of the hypotheses testing show that even though general business skills were ranked lower than general technology skills, this difference was not significant. The results also show that general technology skills were ranked significantly greater than specific technology skills. Finally, though general business skills were ranked greater than specific technology skills, this difference was also not significant.

Table 2

Paired Samples Statistics

\begin{tabular}{|c|c|c|c|c|c|}
\hline & & Mean & $\mathbf{N}$ & Std. Deviation & Std. Error Mean \\
\hline \multirow[t]{2}{*}{ Pair 1} & $\begin{array}{l}\text { General business skills overall }(1= \\
\text { lowest importance; } 10=\text { highest } \\
\text { importance) }\end{array}$ & 7.83 & 18 & 1.200 & .283 \\
\hline & $\begin{array}{l}\text { General technology skills overall ( } 1 \\
=\text { lowest importance; } 10=\text { highest } \\
\text { importance) }\end{array}$ & 8.33 & 18 & 1.495 & .352 \\
\hline \multirow[t]{2}{*}{ Pair 2} & $\begin{array}{l}\text { General technology skills overall ( } 1 \\
=\text { lowest importance; } 10=\text { highest } \\
\text { importance) }\end{array}$ & 8.33 & 18 & 1.495 & .352 \\
\hline & $\begin{array}{l}\text { Specific technology skills overall }(1 \\
=\text { lowest importance; } 10=\text { highest } \\
\text { importance) }\end{array}$ & 7.06 & 18 & 1.798 & .424 \\
\hline \multirow[t]{2}{*}{ Pair 3} & $\begin{array}{l}\text { Specific technology skills overall ( } 1 \\
=\text { lowest importance; } 10=\text { highest } \\
\text { importance) }\end{array}$ & 7.06 & 18 & 1.798 & .424 \\
\hline & $\begin{array}{l}\text { General business skills overall }(1= \\
\text { lowest importance; } 10=\text { highest } \\
\text { importance) }\end{array}$ & 7.83 & 18 & 1.200 & .283 \\
\hline
\end{tabular}


Table 3

Paired Samples Test

\begin{tabular}{|c|c|c|c|c|c|c|c|c|c|}
\hline & & \multicolumn{5}{|c|}{ Paired Differences } & \multirow[b]{3}{*}{$\mathrm{t}$} & \multirow[b]{3}{*}{ df } & \multirow[b]{3}{*}{$\begin{array}{l}\text { Sig. (2- } \\
\text { tailed) }\end{array}$} \\
\hline & & & & & \multicolumn{2}{|c|}{\begin{tabular}{|l}
$95 \%$ Confidence \\
Interval of the \\
Difference
\end{tabular}} & & & \\
\hline & & Mean & $\begin{array}{c}\text { Std. } \\
\text { Deviation }\end{array}$ & $\begin{array}{l}\text { Std. Error } \\
\text { Mean }\end{array}$ & Lower & Upper & & & \\
\hline Pair 1 & $\begin{array}{l}\text { General business } \\
\text { skills overall }(1= \\
\text { lowest importance; } \\
10=\text { highest } \\
\text { importance) - } \\
\text { General technology } \\
\text { skills overall }(1= \\
\text { lowest importance; } \\
10=\text { highest } \\
\text { importance) }\end{array}$ & -.500 & 2.065 & .487 & -1.527 & .527 & -1.027 & 17 & .319 \\
\hline Pair 2 & $\begin{array}{l}\text { General technology } \\
\text { skills overall }(1= \\
\text { lowest importance; } \\
10=\text { highest } \\
\text { importance }) \text { - } \\
\text { Specific technology } \\
\text { skills overall }(1= \\
\text { lowest importance; } \\
10=\text { highest } \\
\text { importance) }\end{array}$ & 1.278 & 2.492 & .587 & .038 & 2.517 & 2.175 & 17 & .044 \\
\hline Pair 3 & $\begin{array}{l}\text { Specific technology } \\
\text { skills overall }(1= \\
\text { lowest importance; } \\
10=\text { highest } \\
\text { importance) - } \\
\text { General business } \\
\text { skills overall }(1= \\
\text { lowest importance; } \\
10=\text { highest } \\
\text { importance) }\end{array}$ & -.778 & 2.487 & .586 & -2.014 & .459 & -1.327 & 17 & .202 \\
\hline
\end{tabular}

Further analysis was performed on the individual skill topics. On a Likert-type scale of 1 to 10 , the mean value was 5.5. All skills were above 5.5, but a T-Test was performed to see which variables were significantly greater than the 5.5 threshold. The TTest results are shown in Tables 4 and 5. These two tables show that only some of the variables were significantly greater than neutral (i.e., greater than the 5.5. threshold).

The skill topics listed in Table 4 were significantly greater than a neutral (i.e., 5.5) importance: 
An Empirical Study of the Relative Importance of Specific Technology Skills, General Business Skills, and General Technology Skills

Table 4

T-Test Results - Skills Greater Than Neutral Importance

\begin{tabular}{|c|c|}
\hline Skill Topic & p value \\
\hline Specific technology skills overall & .002 \\
\hline MS Office & .001 \\
\hline General business skills overall & .000 \\
\hline Organizational problem solving & .000 \\
\hline Ethics and professionalism & .000 \\
\hline Creativity & .000 \\
\hline Functional business areas & .000 \\
\hline Interpersonal skills & .000 \\
\hline Teamwork & .000 \\
\hline Leadership & .000 \\
\hline Communications & .000 \\
\hline General technology skills overall & .000 \\
\hline Application development & .010 \\
\hline Internet systems architecture and development & .042 \\
\hline Systems networking and infrastructure & .028 \\
\hline Systems integration & .001 \\
\hline Systems analysis and design & .001 \\
\hline Business process design & .023 \\
\hline IT project management & .000 \\
\hline Operating systems management & .044 \\
\hline Security & .001 \\
\hline Maintenance & .008 \\
\hline Testing & .000 \\
\hline Strategic utilization of IT and planning & .030 \\
\hline
\end{tabular}

Table 5

T-Test Results - Skills Not Greater Than Neutral Importance

\begin{tabular}{|l|r|}
\hline Skill Topic & p value \\
\hline Visual Basic & .706 \\
\hline MS Visual Studio & .448 \\
\hline Linux & .701 \\
\hline Routers & .182 \\
\hline Cisco router technology & .348 \\
\hline Oracle database technology & .379 \\
\hline Business models & .369 \\
\hline Evaluation of business performance & .065 \\
\hline Database design and administration & .104 \\
\hline Web page development & .851 \\
\hline Programming & .105 \\
\hline Human-computer interaction & .927 \\
\hline
\end{tabular}

\section{FINDINGS}

Some of the specific findings in this study are somewhat surprising. For example, the most important skill listed was Ethics and Professionalism 
$($ rank $=9.5)$. This is an area that receives little attention in most IT/IS programs. Further, it is difficult to find and cite other studies underscoring the importance of ethics in IT/IS. Most research on the topic is limited to the recommendation of adopting industry standards on ethics, such as those prescribed by the Association of Computer Machinery (ACM), the Institute of Electrical and Electronics Engineers (IEEE), and the Software Engineering Code of Ethics and Professional Practice [16].

The next series of skills (in terms of ranking) are all traditional soft business skills including: Teamwork, Communications, Interpersonal Skills, Organizational Problem Solving, and Creativity, respectively. Though some IT/IS programs have increased emphasis in these areas, few organizations place these skill topics at the top of their list. In recent years, "soft skills" have been ranked increasingly higher by industry. However, employers recommend the IT/IS curricula include soft skills (i.e., communication skills and leadership skills) in addition to, (but not in place of) traditional "hard skills" such as math, programming logic, and data structures. In their 2008 study, Downey, et al. [7], found that employers rate soft-skills and business skills as important as technical skills.

The highest general, non-business skill topic was $I T$ Project Management, which is not included in many IT/IS programs. The high ranking of Project Management is consistent with past studies. For example, the 2006 study by Kim, et al., found that at least one project management course should be included in every IT/IS curriculum. Kim, et al., also found that, while project management is part of the IS 2002 curriculum model, many schools “ . . . have not implemented this course in their programs" [8]. After Leadership Skills, General and Specific Technology Skills take priority and include MS Office (rarely included in current IT programs), Testing (also rarely covered), Security, Systems Analysis and Design, Application Development, Systems Integration, Systems Networking, and Maintenance. The general business skill of Specific Business Areas is also included, which rated behind Application Development.

Perhaps most surprising is the ranking of Programming. Only after all of the aforementioned skills does Programming appear as a general technology skill. With the reduced emphasis on custom software and the move to packaged software, this finding is not surprising. However, many IT/IS

Volume X, No. 2, 2009 programs spend the majority of their course time in programming. The reduced emphasis in programming is, however, consistent with the findings of other studies. For example, in their 2006 industry survey, Bailey and Mitchell found that instead of specific programming skills, " . . . broad based skills, which cut across languages, platforms, and tools are viewed as most important" by employers [1].

The complete list of specific skills (detailed in Tables $1 \mathrm{a}, 1 \mathrm{~b}$, and $1 \mathrm{c})$ provides valuable insight into current skills in today's IT environment.

\section{CONCLUSION}

This study has important implications for researchers, educators, and practitioners. According to findings of the current study, IT/IS educators should emphasize general technical skills (as opposed to specific technology skills) first and foremost in IT/IS curricula. The findings of the current study also suggest that IT/IS educators should emphasize general business skills in their curricula.

For practitioners, these findings serve as the start of a comprehensive study of the skills and talents that are needed in today's IT job market. If educators modify their programs to accommodate these requirements, practitioners should reap the benefits of more skilled employees and higher worker productivity.

Researchers should regard the findings in this study as the start of an exploration of the most important skills that are needed in IT/IS today. However, the findings of this study cannot be generalized to other geographic markets within the United States, within all types and sizes of organizations, and to industries within other countries. Therefore, further analysis is needed to generalize the findings to a broader population of organizations and geographic regions.

\section{REFERENCES}

1. Bailey, J. \& Mitchell, R. (2006). Industry perceptions of the competencies needed by computer programmers: technical, business, and soft skills. The Journal of Computer Information Systems, 47(2), 28-33.

2. Boyle, T. \& Strong, S. (2006). Skill requirements of ERP graduates. Journal of Information Systems Education, 17(4), 403-412.

3. Cappel, J. (2002). Entry-level IS job skills: a survey of employers. The Journal of Computer Information Systems, 42(2), 76-82.

4. Crews, T. (2004). Telecommunications course 
content: input from information technology professionals. Journal of Information Systems Education, 15(4), 417-425.

5. Davis, D. \& Woodward, B. (2006). An analysis of skills required of graduates of an information systems program. Information Technology, Learning, and Performance Journal, 24(2), 1121.

6. Dillon, T. \& Kruck, S. (2008). Identifying employer needs from accounting information systems programs. Journal of Information Systems Education, 19(4), 403-410.

7. Downey J., McMurtrey, M., \& Zeltmann, S. (2008). Mapping the MIS curriculum based on critical skills of new graduates: an empirical examination of it professionals. Journal of Information Systems Education, 19(3), 351-363.

8. Kim, Y. Hsu, J. \& Stern, M. (2006). An update on the IS/IT skills gap. Journal of Information Systems Education, 17(4), 395-402.

9. Koong, K., Liu, L., \& Liu, X., (2002). A study of the demand for information technology professionals in selected Internet job portals. Journal of Information Systems Education, 13(1), 21-29.

10. Kovacs, P. J, Davis, G. A., \& Caputo, D. J. (2008). Analyzing the progression of IS/IT keywords as assessed by a regional trade association. Information Systems Education
Journal, 6(1).

11. Lee, C. \& Han, H. (2008). Analysis of skills requirement for entry-level programmer/analysts in Fortune 500 Corporations. Journal of Information Systems Education, 19(1), 17-27.

12. Lee, S. \& Fang, X. (2008). Perception gaps about skills requirement for entry-level is professionals between recruiters and students: an exploratory study. Information Resources Management Journal, 21(3), 39-63.

13. Martz, Jr. W. \& Landof, G. (2000). Information systems careers: a comparison of expectations. The Journal of Computer Information Systems, 40(2), 41-45.

14. McCoy, R. (2001). Computer competencies for the 21 st century information systems educator. Information Technology, Learning, and Performance Journal, 19(2), 21-35.

15. Schwartz, E. (2006, June 29). Brushing up on your soft skills. Retrieved April 5, 2009, from InfoWorld:http://www.infoworld.com/t/business/ brushing-your-soft-skills-045

16. Towell, E., Thompson, J., \& McFadden, K. (2004). Introducing and developing professional standards in the information systems curriculum. Ethics and Information Technology, 6(4), 291299 